$\begin{array}{ll} & \text { Etnográfica } \\ \text { etnográfica } & \text { Revista do Centro em Rede de Investigação em }\end{array}$

Antropologia

vol. 17 (3) | 2013

Vol. 17 (3)

\title{
Enchanting spaces: echo and reverberation at Romanian popular parties
}

Espaços de encantamento: eco e reverberação em festas populares romenas

\section{Victor A. Stoichiță}

\section{(2) OpenEdition}

\section{Journals}

\section{Electronic version}

URL: https://journals.openedition.org/etnografica/3281

DOI: 10.4000/etnografica.3281

ISSN: 2182-2891

\section{Publisher}

Centro em Rede de Investigação em Antropologia

\section{Printed version}

Date of publication: 30 October 2013

Number of pages: 581-603

ISSN: 0873-6561

\section{Electronic reference}

Victor A. Stoichităa "Enchanting spaces: echo and reverberation at Romanian popular parties",

Etnográfica [Online], vol. 17 (3) | 2013, Online since 31 October 2013, connection on 09 February 2022 URL: http://journals.openedition.org/etnografica/3281 ; DOI: https://doi.org/10.4000/etnografica.3281

\section{(c) (i) (8)}

Etnográfica is licensed under a Creative Commons Attribution-NonCommercial 4.0 International License. 


\section{Enchanting spaces: echo and reverberation at Romanian popular parties}

\section{Victor A. Stoichiţă}

This contribution describes how Roma professional musicians in Romania use electronic sound processing for live performances in various contexts. It focuses on four techniques - amplification, mixing, reverberation and echo - which are intimately linked in the practice of these musicians. The latter two effects are modeled on natural acoustic phenomena, but are used by the musicians to create sound environments with artificial, impossible or paradoxical properties. The article details how these techniques are used, in relation to the typical interactions between the musicians and their audiences. This leads to the argument that artificial echo and reverberation (building upon amplification and mixing) are used by Roma professional musicians as techniques to "enchant" both the performance places and the social relations which they host.

KEYWORDS: Roma/Gypsies, music, space, enchantment, agency.

Espaços de encantamento: eco e reverberação em festas populares romenas - Este texto descreve a forma como os músicos profissionais rom (ciganos), na Roménia, usam o tratamento eletrónico do som em espetáculos ao vivo em diferentes contextos. Centra-se em quatro técnicas - amplificação, mistura, reverberação e eco - intimamente ligadas entre si na prática destes músicos. Os últimos dois efeitos têm como modelo fenómenos acústicos naturais, mas são usados pelos músicos para criar ambientes sonoros com características artificiais, impossíveis ou paradoxais. É aqui detalhada a forma como essas técnicas são utilizadas e como se relacionam com as interações habituais entre os músicos e o público. Isto conduz ao argumento de que o eco e a reverberação artificiais (conseguidos com base na amplificação e no mixing) são usados pelos músicos profissionais rom como técnicas para "encantar" tanto os lugares onde ocorrem os espetáculos como as relações sociais que eles encerram.

PALAVRAS-CHAVE: ciganos rom, música, espaço, encantamento, agencialidade.

STOICHIŢÃ, Victor A. (victor.stoichita@mae.u-paris 10.fr) - Laboratoire d'Ethnologie et de Sociologie Comparative (LESC/CNRS - Nanterre), France. 
IN SOUTHEASTERN EUROPE, ROMA PROFESSIONAL MUSICIANS ARE often hired to provide entertainment for large and popular events such as weddings, christenings, circumcisions, birthday parties or political rallies. Some of them also perform on a regular basis in pubs or restaurants. In Romania, such musicians are called lăutari.

Lăutari play a variety of instruments throughout the country. To give a quick overview, brass and reed instruments are very popular in the Northeastern and Western regions (Moldavia and Banat), accordions are the trademark of Bucharest and the South (Oltenia), violins are appreciated all over the country, with pure string ensembles operating in the Northwest (Transylvania). Although fewer nowadays, cymbalums can still be heard here and there, and are often held in high esteem by the connoisseurs. In the 1970s probably (Rădulescu 2002: 75-76), the lăutari started to use musical electronics for amplification and for sound effects. Synthesizers were introduced during the 1980s, and with the help of the microphone, singers became an integral part of genres where voices would otherwise have been unheard. Drumkits were frequent until the turn of the century, when they started to be replaced by the drum machines of the synthesizers. The lăutari form a highly gendered profession, most of them being male. Some females do however perform as singers.

Nowadays, only few Roma ensembles play without amplification. Almost inevitably, this also means reverberation and echo. Added on the mixing console, the latter effects emulate the reflection of sound waves on the surfaces they encounter in natural environments. The way in which the lăutari use these techniques stands at the core of the present article.

From a listener's point of view, reverb and echo may be understood as either properties of spaces or properties of sounds. For its major part, our experience of the world advocates in favor of the first view. In naturally sounding environments there are indeed stable relations between the properties of physical spaces (dimensions, shapes, textures of their bounding surfaces and the objects which they contain), and the ways in which they reflect sounds. This results in implicit indexical inferences whereby we assume that "reverberation and echo simply are sonic attributes of physical space" (Doyle 2005: 14; see also Stroffregen and Pittenger 1995). However it is also possible to tweak the sound waves to alter their indexes of spatiality. This is how echo and reverberation can effectively suggest spaces which do not actually exist in the physical sense (they can only be heard, not seen or touched). These effects can serve various purposes. Sound engineers for instance know how to use echoicity to give very realistic sensations of space, ones which cannot be distinguished from live recordings in similar spaces (see Frederickson 1989). ${ }^{1}$ But the same 
effects can also be used to depart from realism and create spaces which can only exist in sound. As I shall illustrate below, the lăutari use extensively the latter possibility as a technique to "enchant" (in the sense of Gell 1988, 1992, 1996, 2006) the performance space.

Recorded media make it evident that echo and reverberation are carefully crafted by musicians and/or sound engineers in many musical traditions around the world. These techniques have been described in detail for Anglo-Saxon popular music by Zak (200 I: 70-85), and by Doyle (2004, 2005). The latter's book is a thorough analysis of echo and reverberation, as tools to "fabricate space" in early American pop. Greene (2002) described echoicity in Nepali lok pop music. He showed its links with the cultural tensions between cities and villages, valleys and mountains, and with other aspects of Nepali politics. His work contains detailed descriptions of the actual techniques used, and analyses how they are understood by musicians, listeners and sound engineers. Other anthropologists and ethnomusicologists have mentioned on occasion the importance of electronic echoicity in the music they dealt with. Hesselink (1994) for example explained that adding reverb and echo was a key step in the design of karaoke in Japan. Douglas (2005) described how the same effects fitted into the aesthetics of Burmese folk music market. Levin, on the other hand, deplored that in Uzbekistan "performers and audiences alike have become addicted to electronic reverb” (Levin 1993). Apart from Greene, ethnomusicologists and anthropologists have not been keen however to dive into detailed descriptions of these techniques.

Precision is important here, though. Even in closely related musical styles, detailed analysis may reveal considerable differences in the uses and understandings of echoicity (see Doyle 2005; Greene 2002). The more so, one may expect, when considering different musical cultures, on a larger scale. Artificial echo and reverberation offer good grounds for cross-cultural comparisons. Their perception relies on shared cognitive processes, and they are produced using a limited set of techniques. On the other hand, their "affective" impact, and their pragmatic uses seem prone to great cultural variation. In this paper, I will draw comparisons between lăutari's uses of these techniques and the data currently available in the aforementioned studies. Additional data, from other musical traditions, would allow, no doubt, to refine the picture.

My argument is based on field ethnography with lăutari, customers and occasionally sound engineers in Romania. ${ }^{2}$ I will refer primarily to live

springs of plates. Actual echo was achieved by playing back with a slight delay two or more magnetic tapes bearing the same content. Nowadays virtually all artificial reverberations and echoes rely on electronic sound processing.

2 From 2001 to 2006 I carried several fieldworks in rural areas and small urban settings in the Moldavian region, around the village Zece Prăjini, with the help of a grant from the Université Paris Ouest Nanterre La Défense. I worked with professional musicians, in both amplified and non [continues] 
performances, and only secondarily to recording techniques. This is a significant difference from most of the works cited above. Indeed, studio recordings have been important in the development of many popular songs. They lie at the core of well known business models (see for example Frith 1981 on AngloSaxon pop). On the other hand, Roma professional musicians in the Balkans earn most of their income by performing live for various events (Pettan 1996; Rădulescu 1996). They do record in studios, and quite abundantly so, but in their business model, they treat recorded media as mere "advertisements" of their skills (Stoichiţă 2010).

The core of this contribution describes how Roma musicians in Romania use electronics to provide an immersion experience for their listeners. The first part gives a brief overview of the typical acoustic environments at parties with live musicians. The second part focuses on their use of the amplifier and mixing console, with its integrated reverberation and echo effects. The latter are intimately linked to the aesthetic properties of the music being played, and respond in particular to the audiences' inclination for "startling", "cunning", and "special" effects. In the third part, I illustrate how echoicity interacts with lyrics and musical structures in a particular genre, the manea, which local commentators describe as a particularly "exotic" kind of music. In conclusion, I argue on the interest of viewing these sound practices as techniques to "enchant" (Gell 1988, 1992, 1996) spaces and the social relations which they host. I suggest that they accentuate music's tendency to build disconnected, heterotopic and otherwise paradoxical spaces.

\section{THE SETTING}

\section{How professional musicians understand their work}

The activities of Roma professional musicians in Romania (the lăutari) have been described by various authors. ${ }^{3}$ The reader unfamiliar with this literature may get a glimpse of the way lăutari themselves comment on their work through the following excerpt. It is taken from a discussion with a young keyboard player, as we were driving back from a christening party where he had been performing with three of his colleagues.

[continued] amplified ensembles (see Stoichiță 2008). In 2009-2010, I carried ten months of fieldwork on amplified music in Bucharest, with the support of a fellowship at the New Europe College. A significant part of this paper was written while I was working at the Instituto de Etnomusicologia (INET-MD, FCSH/UNL) in Lisbon, with the help of a grant from the Portuguese Foundation for Science and Technology (FCT). I presented earlier versions of this paper at the meetings of the SIEF in Lisbon in 201 1 , and of the Milson project (www.milson.fr) in Paris, in 2012. I am grateful to the many colleagues in these research networks who voiced insightful remarks to help me inform the argument presented here.

3 For general data on the lăutari, see Beissinger (1991, 2001), Bonini-Baraldi (2013), Ciobanu (1969), Lortat-Jacob (1994), Rădulescu (1984, 1988, 1997, 2004) and Stoichiţă (2008). 
"Generally, the lăutari manage in any circumstance. They have a kind of special training... You see the customer and you know how to please him. That's it. It's like being an actor. I mean this for the lăutari who deal directly with the people, especially the singers. A 'rear' instrumentalist just stays there and does his business. But the one with the voice, if he's dumb, he can get all his mates into trouble. So as a singer, you have to be very careful. You have to be a thief! And a smart guy (smecher) too. You have to be psychologist... Being a lăutar is about being clever" [interview with Felix L., Bucharest, November 2009]. ${ }^{4}$

One thing is clear here, as in many other statements by the lăutari: they perform as professionals, with the explicit intent to fulfill the musical desires of their customers. ${ }^{5}$ They do not place emphasis on "expressing" themselves or "communicating" their own feelings. They take pride in being "emotion makers", and portray their work in a paradigm of affective manipulation (Stoichiţă 2008). This is also how their customers like them to be. A good professional plays well what is appropriate for his listeners, and this does not necessarily correspond to his own feelings at that time.

As can be felt in Felix's comment, relations of power during such musical interactions are often ambiguous. On the one hand, music gives the lăutari great control over the collective atmosphere, the emotions and the bodies of their listeners (which they impel to dance, to cry, etc.). On the other hand, economical and physical power is clearly in the hands of the customers. The discrepancy is often accentuated by an ethnic split, as most customers are ethnic Romanians, and being a lăutar is typically a Roma job. However, while ethnicity is an important aspect of these interactions, its consequences are not straightforward. Indeed, Roma identity in Romania is very fluid and multi-faceted, and the tensest situations I could witness were actually at parties where Roma musicians played for Roma customers of a different group. ${ }^{6}$ Generally speaking, whatever the ethnic, social or cultural context, to perform as a lăutar means to endorse a certain kind of professionalism. This brings along particular relations of power, whereby musicians serve and, at the same time, control their customers.

Another aspect to which Felix alludes is the functional separation between instrumentalists and singers. While the former "just do their business", the

4 Felix L. is 33, father of one daughter, was born in the north-east countryside, and has been living in Bucharest for 10 years now. He performs with various ensembles, in Bucharest or traveling to the villages nearby. Apart from the keyboard synthesizer, a typical band in this area would include a singer and one or several amplified melodic instruments, like violin, saxophone or accordion.

5 The lăutari are professional musicians in the sense that music is their main source of economic income. Not only are they paid to perform, but they rely on it to provide a living for their household. 6 For a recent discussion see Olivera (2012). For an analysis of lăutari's specific position in relation to other Roma groups, see Beissinger (2001). 
latter act as an interface between the listeners and the rest of the band. They lead the performance, indicating which tunes should be played, in which key, speeding up or slowing down the tempo, and making "special announcements" on the microphone.

These announcements are generally made on behalf of specific individuals in the audience. The announcer pays a "tip" (baç̧iş) to the singer, and either orders for a specific tune or simply addresses the one currently being played as a "dedication" (dedicaţie) to someone else. The singer announces on the microphone something like: "From Gigel, for Nina, this nice tune, thank you very much!" (Din partea lui Gigel, pentru Nina, melodia asta frumoasă, mulţumim frumos!) The amount of the "tip" is sometimes announced as well.

These interactions often require subtle social skills of the singer. Amongst other things, he must take care to give due credit to "important" wealthy dedicators (barosani), without upsetting the other guests, who should also feel respected. Singers act like masters of ceremony, and their position on the borderline between emotion making and empathetic feeling is particularly delicate. They stand physically closer to the audience than any other musician. As of 2012, most of them perform right near or amongst the dancers, using wireless microphones. A singer is also more expressive and may, for example, sketch a few dance steps himself during an instrumental break... But this is still a job, as Felix makes clear, and such positions are taken by the singers on behalf of the whole band. ${ }^{7}$

The end of Felix's comment is amongst the commonest statements in lăutari's talk: good musicians should be clever, smart, cunning, sly... In a word şmecheri. Being şmecher goes beyond negotiating with the customers. A whole set of aesthetic comments evolve around the notion of musical "trick", for which şmecherie (the action of the şmecher) is also a common name. In their evaluations of musical performances, lăutari and connoisseurs tend to value cleverness and cunning, which they attribute to the musicians but also, somehow paradoxically, to the tunes themselves (Stoichiţă 2008, 2011 ). As we shall see, musical electronics are also a way to extend this general aesthetic of virtuoso techniques and "special" effects. Before moving on to them, I will describe briefly the kind of acoustic settings in which the lăutari perform.

\section{On the listeners' side}

From a listener's point of view, popular parties can be divided in two broad acoustic categories. On the one hand, open spaces: backyards hosting wedding parties, christenings occupying part of the street in front of a house, political meetings or village fairs organized in the open space near the church... Such

7 The singer's position is illustrated by a translated video example at $<$ www.svictor.net/enchanting -spaces $>$. 
performance contexts are typical of the countryside, but may be encountered in urban areas too. The sound emanates from the musicians and propagates over a wide area. Dance usually occurs in one group, in front of the musicians. At night, an electric spot is placed there to light it up. Participants come and go. Some of them aggregate in lumps around the dancers, others remain seated at the tables where food and drinks are served, teenagers look for darker places to smoke cigarettes and flirt.

This contrasts with closed performance spaces, like town halls, restaurants or night clubs, which offer soundscapes of a much more compact kind. They host similar events. But here the rumor of the party vanishes quickly outside the walls. Inside, sonic space is remarkably homogeneous and not really structured around the musicians. Just as outdoors, the amplifiers are pushed to their limits. But reflected by the walls and the ceiling, decibels do not really decrease as one walks away. The experience of being bathed in sound becomes pervasive. At night, lighting is also more regular than outdoors, as neon bulbs usually span the ceiling evenly. Consequently, dance may take place anywhere. It is often split in several independent groups, some near the musicians and some further away. Verbal interactions and intimacy are difficult everywhere inside, and become suddenly easier outside.

Outdoors as indoors, listeners are free to adopt a wide range of attitudes. Only few moments require everybody's attention or coordinated involvement. The party forms a net of interactions where the musicians and their apparatus are only one node amongst others, albeit a special one.

Most participants do not even look at them, and it is unclear how many people actually listen to what is being played. The lăutari often stand on the floor, at the same level as the guests. If a stage is available, they do occupy it, but everyone can walk and speak to them (for example to make the aforementioned "dedications"). So the stage is not a reserved space, as it would be, for example, in a folkloric concert. Moreover, when performing manele, the singer often stands amongst the dancers, sometimes with a melodic instrument near him. In brief, from the listener's point of view, the lăutari are just as physically accessible as anybody else.

In sound, however, musicians' position is quite peculiar. They manipulate a number of decibels unavailable to anyone else in the audience. Their shiny instruments, electronic gear and technical skills, which they display with pride, clearly surpass those of the customers. They master the soundscape, taking up a kind of sonic "stage", where nobody enters without their assistance, and which spreads all over the party. ${ }^{8}$

8 One may get a sense of the way such a live performance sounds, through the recorded excerpts published on <www.svictor.net/enchanting-spaces $>$. The reader could listen in particular to Gicuţă din Apărători and his band performing a manea song during a Roma wedding in Olteniţa. [continues] 


\section{SOUND TECHNIQUES}

\section{Amplification (and its mix)}

As used by Roma musicians, musical amplification can be described in four stages, as follows.

1. An electronic signal is generated for each instrument. As we have seen, the lăutari play various instruments, both "acoustic" and electronic. ${ }^{9}$ The vibrations produced by "acoustic" instruments (violins, accordions, the voice, etc.), are transformed into electric signals through microphones or contact sensors. Electronic instruments (like synthesizers or electric violins) produce electronic signals straight away. All outputs are monophonic, except for the synthesizer which is stereophonic.

2. The signals from different sources are tweaked and blended together. This is done on a mixing console. In 2010, in Bucharest, the most popular console amongst the lăutari was probably the Dynacord Powermate 1000 (hereafter DP1000; see figure 1). Through its many knobs and settings, the musicians focus on a limited number of acoustic variables.

a) The minimal choice is to determine the relative level of each instrument in the final mix (how loud the violin, the voice, etc.). This is done through the "gain" knob, and the "level" slider.

b) One can also balance each instrument's position in the right-left panoramic. This is done through the "pan" knob. The lăutari set most "pan" knobs at their middle position.

c) A very frequent step is to tweak the "equalization" of each signal. The DP 1000 integrates three knobs per track, for bass, medium and treble frequencies. Equalization is crucial for microphones, as it allows to cut off some of the frequencies which would otherwise cause a Larsen effect (the "hiss" or "woo" sound which results from the feedback of the speakers into the microphone).

d) Electronic echo and reverberation are added in variable amounts to each track. These effects are built directly into consoles such as the DP1000. On devices which do not integrate them, the musicians use external effect units (linked to the console as "sends").

[continued] I will come back later to this example.

9 According to the Merriam-Webster dictionary, an acoustic instrument is "a musical instrument whose sound is not electronically modified" (<http://www.merriam-webster.com>, consulted on $22 / 04 / 2012)$. Here I use the word for instruments which are able to produce self-standing sounds without the aid of electronics, even if some processing is later applied to them. 


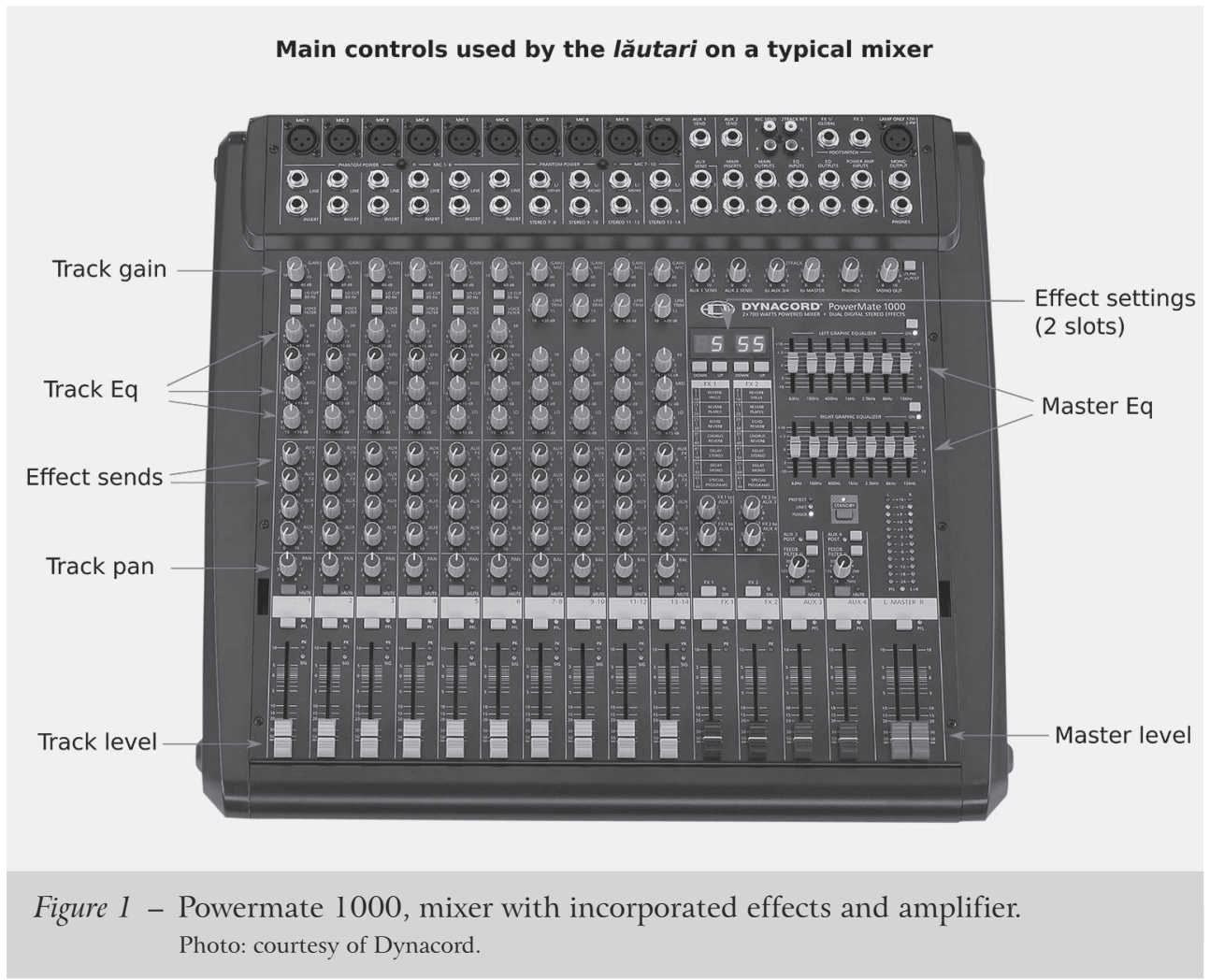

e) The output of each track is routed to the "master track". This accomplishes the final mix and results in a stereo signal (two channels: left and right).

3. The stereo signal is amplified. Until now, its electric power was somewhere below the Watt; after amplification, it is hundreds or thousands of Watts. The DP1000 for example delivers 2 x $700 \mathrm{~W}$. Some musicians prefer to use external amplifiers (especially when these are built into the loudspeakers, as they usually offer more power).

4. The signal is sent to the loudspeakers, where it becomes sound.

I have detailed these operations in order to highlight that amplification is not merely a matter of helping the band play louder. It is intimately linked with mixing, which in turn determines the relative positions of the instruments in the overall soundscape. These are actually created on the mixing console. The voice, for example, doesn't reach it "to the right" or "to the left" of the violin. It will only sound so after the "pan" knob. And if the latter is set at its middle position, both musicians will be heard "in the middle", 
even if one is near the right loudspeaker and the other far away, amidst the dancers. Similarly, whether the violin was louder or softer than the saxophone in the "acoustic" world doesn't matter anymore. The "gain" and "level" settings take precedence and reorganize the fore- and backgrounds of the sound. Electronic instruments such as the synthesizer don't even sound at all before amplification. Hence there is no clearcut difference between "mere" amplification and sound effects. Amplification implies mixing and, together, their result is a sonic construct which is already a kind of special effect, in the sense that it turns real a space otherwise impossible. ${ }^{10}$ Echo and reverberation, to which I turn in the next section, are refined ways to control its dimensions.

The creation of artificial soundscapes is a general outcome of mixing and amplification techniques, and the same operations are available on all mixing consoles. It doesn't concern the lăutari solely. Cultural peculiarities appear in the details, however. For example, referring to step 1 above, since the middle of the 2000 decade, the lăutari have given up on using microphones for saxophones and clarinets. They now prefer contact sensors (originally devised for instruments with soundboards), which they stick directly between the reed and the mouthpiece of the instrument. In their words, the advantage is a powerful and warm sound without the risk of Larsen feedbacks. This sound is far from the "natural" resonance of the instrument and would probably be deemed unsuitable by most rock or jazz bands. But for the lăutari, artificiality is a feature, not a problem. The new sound of reed instruments fits well, for example, the tones of the synthesizer. ${ }^{11}$ Likewise, setting the "pan" knobs (step 2b) at their middle positions reflects the lăutari's preference for blended sound sources (as opposed to their distribution along the right-left panoramic). The output is not strictly monophonic however, as the synthesizer enters the mix in stereo, and as later (step 2d) reverberation and echo add their stereophonic quality to the other parts.

\section{Echo and reverberation}

Along with amplification, reverberation has become a standard effect amongst Roma musicians. It can be heard in virtually any performance, usually in large

10 On the notion of special effects in an anthropological perspective, see Grimaud, Houdart and Vidal (2006).

Il The "standard" keyboard in 2009 was the Roland G800. The lăutari typically used the sounds named "strings", "slap bass", "plucked guitar" (but usually after modifying the factory defaults, so the names themselves do not tell much). They also used the synthesizer's incorporated drum machine. The role of the keyboard player was primarily to hold the harmony, by playing the bass line on the left hand and some rhythmic chords on the right one. If a second keyboardist joined the band, he would perform melodic lines. 
amounts. The musicians call it either reverb or hal. ${ }^{12}$ In live settings, Roma musicians generally add to it a large trailing echo, named ecou or dilei (from the English word "delay"). This is only for voices and melodic instruments, never for drums or harmony synthesizers. Echo never appears on recorded media either, where only reverb is to be heard.

Reverberation and echo are different effects, but their basic principle is the same. Both repeat the input signal with a delay. In doing so, they mimic the natural reflection of sound waves on the surfaces they encounter. In the "real" world, reflection delay is strictly correlated to distance. Reverberation is perceived when the reflected sound wave reaches the ear less than a certain amount of time after the direct signal. Since the original sound wave is still held in memory, the two waves tend to combine perceptually as one very prolonged sound. When the delay increases above that threshold, the brain starts to analyze the second sound as distinct. We then hear an echo. ${ }^{13}$

In an ecological environment, a 100 millisecond reflection means a distance of about 17 meters. Such relations are fairly constant and humans (as most hearing animals) implicitly link physical spaces to the way they sound. ${ }^{14}$ But in electronic music, delay and decay are manipulated independently of actual physical distance. Reverberations and echoes with "impossible" characteristics are then easily achieved.

Apart from decay times, other variables play a role in our acoustic perception of space. The most important are early reflection time, spectral damping and stereo spread. ${ }^{15}$ These variables (and sometimes others as well) can be set independently on most studio effect units. On stage, rock and pop artists typically use foot-pedals, which only have buttons for a smaller subset of these settings. The approach of the lăutari is yet different: their reverberation and echo are added through presets directly on the mixing console. The DP1000 for example has two effect slots. Each of them can hold one of twenty kinds

12 The latter word most probably refers to one of the typical settings of electronic reverberation units (named "hall" for it is supposed to sound like a concert hall). In Romanian, hal happens to also mean a messy state of things.

13 Psychoacoustic experiments indicate that echo perception thresholds vary depending on the kind of signal (clicks, words, music...), its amplitude, and other situational parameters (see Blauert 1997: 224 sq.). In musical sound engineering, echoes usually start at delays of 100 milliseconds. Those of the lăutari are typically around 400-500 milliseconds. This is well above the thresholds measured experimentally, some of which are as short as 20 milliseconds.

14 All humans seem to have some echolocation abilities, and blind people can develop sophisticated skills in this respect (see Stroffregen and Pittenger 1995).

15 The damping of high frequencies implies that the reflection surface is probably of a soft material and/or that there are other damping objects between it and the listener. Stereo spread is linked to the size and complexity of the resonance space. Early reflection is a kind of "one time echo", which occurs in very large spaces, where the reverberation starts after the initial signal with a delay longer than the echo threshold. 
of reverbs, twenty kinds of delays, or ten kinds of echo reverbs. The effect for each slot is chosen through a number on the digital display.

Using presets has two interesting consequences. Firstly, the soundscapes of amplified ensembles across the country are remarkably homogeneous. Even though instruments and musical styles vary according to the region, the space in which modern lăutari sound is built everywhere with virtually the same tools and the same presets. Homogeneity is a desired effect, as most musicians do not seek to develop "their own" sound, but rather to play with "fashionable" techniques. Secondly, homogenization also affects the sounds of the instruments inside the band. All inputs are routed through the same reverb and echo. The musicians simply choose their amounts for each part (more on the voice, less on the drums, etc.). By using overall settings from the mixer (rather than individual foot-pedals, for example), and by locating all the tracks at the middle of the left-right panoramic, the lăutari create a remarkably homogeneous "sound-box" (in the sense of Moore 2001: 106). The sound of each protagonist stems right out from the middle (wherever his physical position in the performance space) and reflects itself exactly with the same delay, exactly on the same virtual "walls". This not only blends the instruments together. It also enhances the impression that musical space exists "independently" of the performers. Indeed, even when one of them stops, there is always someone else to keep the space "alive" through his own reflections.

\section{ENCHANTING SPACES}

\section{Why use reverberation and echo?}

In my discussions with lăutari, some words were recurrent to describe the intended effects of amplification, reverberation and echo. Amplification was about "power" (putere), and the amplifier unit itself was sometimes called "the power" (puterea). ${ }^{16}$ Interestingly, performing unamplified was not commented as "unpowerful" but rather as "cold" (la rece, lit. "in the cold"). Indeed, "power" was a feature of good music anyway, whether amplified or not. Virtuosistic or "clever" (şmechere) musical structures were intrinsically "strong" (tari). They had the capacity to "break down" the listener ( $a$-l sparge / te poraues-les) by themselves, even when performed "in the cold" (la rece). Some techniques on the mixer could enhance this violent pleasure. For example "giving attack" to the sound ( $a-i d a$ atac), was achieved by pushing the gain buttons slightly into distortion. Similarly, the "power" of a band was linked to its "compact" sounding (positive comments compared it to a tank or an army for example).

16 Like in "The mixer and the power are from Behringer" (mixerul şi puterea sunt de la Behringer), or "I bought a power two months ago, and it's already broken" (am cumpărat o putere acum două luni şi deja s-a ars). 
The blending of its different parts on the mixer enhanced this desired effect of "compactness". In all respects, amplification merely continued an aesthetics of power which was relatively independent of it. Reverberation and echo, on the other hand, seemed to add a specific set of abilities.

Some musicians described reverberation as a way to "warm up" the sound (încălzeşte sunetul), and to "open" it (deschide sunetul). This "opening" could be understood as an ontological property. "Open" (deschis) and "closed" (închis) are the Romanian words for "light" and "dark", in relation to colors for example. But considering lăutari's general concern for the effects of their playing, the metaphor could also be understood in reference to the sound's "accessibility". In this sense, an "open" sound (un sunet deschis) was one in which the listener could "enter" easily.

During my early fieldworks in Zece Prăjini (2001-2006), I worked with young musicians to produce "demo" recordings which they could use to promote their skills. ${ }^{17}$ While mixing the tracks to achieve the final output, they usually preferred much deeper reverberations for the melodic instruments than those which I would have used spontaneously. ${ }^{18}$ Several musicians commented my initial mixing suggestions (with less reverb) as "too harsh" (prea dur) or "too direct" (prea direct). It was as if the impression of "power" (putere), which they seeked at many levels, had to be tempered or, in their words, "opened" (a deschide) to the listener.

With less reverb, the musicians were immediately present, on the very surface of the earphones or loudspeakers. The larger the reverb, the more the musicians seemed to "step back" into the distance. The place of the encounter, then, was no longer the actual space of the listener but a special and somehow "utopian" one. This effect of echoicity is a deliberate choice in other musical traditions (see Doyle 2005: 9). The lăutari which I met were not so explicit about it but they seemed to share the concern that listeners should be allowed enough space to "enter" and project themselves into the musical realm.

Echo is even more of an interaction technique than reverb. As we have seen, it is only used in live performances. The lăutari described it as a tool to address three kinds of concerns. Some musicians considered that it helped to "hide"

17 These were multi-track recordings of one or more melodic instruments accompanied by a synthesizer which played harmony and provided drums. I recorded on my laptop, using an external soundcard and microphones. As my soundcard only had two inputs, the workflow often involved some playback (for instance recording the stereo synth in one take, and the mono saxophone in another). This resulted in the necessity of a final mix, which often brought into discussion the appropriate ways to construct a musical soundscape. Many of the comments on which I base my analysis of reverberation were gathered during such interactions.

18 Amongst all settings available in my software, they preferred "plate" reverbs (a kind of reverb where reflections are dense and build up quickly, with a rich spectrum). Decay times were around 2 seconds. 
away or "camouflage" small errors (le mai ascunde/camuflează). The opinion that "effects hide the defects" is widespread amongst musicians, in Romania as elsewhere. It may seem paradoxical in the case of echo, which literally repeats the offending sounds. But once blended into the trail, small mistakes no longer stick out disgracefully (and as many improvisers know, repeating a jarring sound several times is a good way to make it sound acceptable indeed).

According to my interlocutors, another good reason to use echo in live performances was its tendency to create "automatic" musical patterns. In their settings, the delay between successive echoes generally remained constant throughout the whole event, typically around 400-600 milliseconds. Now each kind of tune has a typical tempo: there are fast dances, moderately fast dances, slow songs for still listening, etc. The tempo of the drum machine is fine tuned by a wheel on the synthesizer. The musicians often use it to adapt the performance tempo to the echo delay. They try to match an integer number of echoes between the beats: one for very fast dances, two, three and sometimes four echoes for slower tunes. The important thing is to have them synchronized with the pulse. ${ }^{19}$ Synchronized echoes not only enlarge the sound, but also create rhythmic patterns "automatically". Musicians explained to me that this helped them to perform at length. Singers and blowing instrumentalists were particularly grateful to the echo. Now they could breathe at ease. With echo their melodic lines became full, continuous and pulsated on the beat, all effortlessly.

The third kind of reason invoked by my interlocutors was that echo helped them to domesticate the natural resonance of the performance space. Natural reverberation was commented as a mere "chaos" (haos). Undisciplined waves would simply come and go between the surfaces they encountered leading to a mess in which one was reluctant to perform. One of the concerns of the lăutari was then to supersede natural acoustics through musical control. Artificial reverberation was not enough for this. Only echo made things sound "neater" (mai curat) and "more arranged" (mai aranjat).

While musicians view echo and reverberation as efficient ways to appropriate the performance space, the audiences experience its transformation into a paradoxical place. Watching a singer or a saxophonist perform is indeed something of a fantastic experience. His body is here, you can touch him, speak to him, ask him to say a few words on your behalf or to play your favorite tune. In sight, corporeal and verbal interactions, he is close, much closer than if he were on a conventional stage for example. But at the same time, the place in which he sounds is not - cannot be - the place where his (and your) body is.

19 On some mixers, there is a "tap" button which sets the delay to the musical tempo by tapping in rhythm. This would theoretically allow the musicians to work the other way round, but I never saw lăutari using it. 
It would take some deep alpine valley to create such an echo, and even then, it would probably not sound like this. Echo in Nepali lok pop or in American rock 'n' roll sometimes strive to bring to mind actual places (Doyle 2005; Greene 2002), but lăutari show no intent to sound "realistic" whatsoever in their use of echoicity. They simply stand at the junction of two realms with incompatible properties: visual and corporeal on the one hand, sonic on the other. This mediating position is part of their ambiguous power and can actually result (if one is "smart" - şmecher) in material benefits.

"Announcements" (anunţuri), dedications (dedicaţii), "commands" (comande/ /cereri) to the musicians have become more frequent since Roma professional musicians play with amplification. At some point of the party, typically when they play manele, one may get the feeling that musicians do not really provide music for the audience anymore. They are constantly interrupted by individuals who wish to dedicate to one another the tunes. The lăutari immediately suspend the melody to relay their announcement (just the drum machine and the echoes are left). When the party heats up, some participants enter into a competitive (or simply generous) mood, and hardly leave the lăutari to develop any significant musical construction. The latter start to act as mere gatekeepers of the musical space. The tips which they receive can then be seen, just as well, as "entrance fees". An enchanted sonic space now stands "by itself", with it ubiquitous power and impossible qualities. Music as such is hardly needed anymore, as the listeners pay to simply project their agencies into it.

\section{Exoticism and heterotopia}

Echo and reverberation are used nowadays by Roma professional musicians for all their repertoire. However, the manea (pl. manele) is a kind of song which deserves special attention in relation to these effects. Firstly, the manea was virtually unknown before 1989, and became widely popular since the fall of the communist regime (on this process see Beissinger 2007; Oişteanu 2001; Rădulescu 2004; Giurchescu and Rădulescu 201 1; Voiculescu 2005). Its rise in popular Romanian culture is concomitant with the spread of amplification and electronic sound effects amongst the lăutari. Secondly, its link with echoicity is emblematic, to the point where parodies of manele songs incorporate the imitation of echo to enhance their comic effect. ${ }^{20}$ Lastly, problematic of place and displacement run through the manea as through no other genre currently performed at popular parties. It is the only style which Romanian audiences deem "exotic" - more precisely "oriental" (orientală), Turkish (tucească), or Gypsy

20 See, for example, two translated videos on <www.svictor.net/enchanting-spaces $>$. One was made for the TV show Puii Mei, which portrays Florin Salam, one of the most renowned singers of manele, in a car wash joint. In the other one (circulated on Youtube from an unknown origin), he supposedly meets Harry Potter. In both clips, and in other similar parodies, the manele singer seems stuck into echoicity, even when he merely speaks. 
(țigăneasc $\breve{a})$ - while still ordering it to the musicians and investing it actively through dance and dedications.

After the collapse of the communist regimes in Eastern Europe, several countries in the Balkans witnessed the emergence of similar trends of popular music. They are called turbo-folk in Serbia, chalga or pop-folk in Bulgaria, musica popullore in Albania or manea in Romania, and share important features (see Buchanan 2007; Silverman 2012). All of them display a paradoxical combination of seemingly incompatible temporal and geographical framings. Through their lyrics, their instrumental tones, and through musical devices such as abundant ornaments, tonal harmony and untempered scales, these genres cultivate stereotyped references to "Oriental" and "Occidental" cultures, as seen from the Balkans. In a typically "orientalist” construction (Said 1979), this double exoticism is altogether geographical and temporal: Eastern and Western dreams melt with considerations about the future and the past (Amy de la Bretèque and Stoichiţă 2012).

Take for instance the following lyrics. They were sung by Florin Salam at several events around 2009:

\author{
Tatăl meu este boier \\ Şi o să-mi ia elicopter \\ Şi o să-mi ia elicopter \\ Să-l plimb pe Salam cu el
}

My father is a boyar $[\approx$ squire $]$ And he'll buy me a helicopter And he'll buy me a helicopter To take Salam on a ride

The helicopter is a modern Western device, and the boyar a land-owner of the Ottoman times. That they would ever be set to rhyme was highly unlikely. They belong to completely different worlds, not only chronologically, but also geographically. The last verse anchors the contrast in the actual performance context. It refers to Florin Salam, who is currently singing it. One may notice that he employs to this effect his own surname rather than the first person pronoun. The latter had appeared just before, but it does not belong to him: the singer takes good care to leave it free for the dedicator or his addressee. The heavy rhythmic pattern, the Phrygian descending melodic line, and the deeply grained voice of the singer all suggest an "orientalist" mood by Romanian standards. ${ }^{21}$

Despite their sometimes assertive statements, manele songs do not convey a determined "message". They do not state "where we are". They provide something rather like a "playground", where listeners are enabled to experiment various social positions and interaction patterns (Stoichiţă 2013). This is achieved with semiotic references, but also by building an actual space where 
listeners are immersed and which stands apart, both geographically and temporally, from any other place which they may experience. This is possibly the most important aspect: as sounds fill in the whole place, these imagined universes gain a degree of immediate presence, which other media hardly achieve. Listeners do not project themselves into a different realm (as if they were watching a movie for example). It is the different realm which comes onto them, immersing their bodies and their familiar places in its particular ambiance.

Talking about places and spaces, Foucault has coined the term heterotopia. While utopias are unreal/ideal places, heterotopias actually exist. In his words, they are "something like counter-sites, a kind of effectively enacted utopia in which the real sites, all the other real sites that can be found within the culture, are simultaneously represented, contested, and inverted. Places of this kind are outside of all places, even though it may be possible to indicate their location in reality" (Foucault 1984). Performed live, manele songs are precisely located in space and time, not only because the musicians are there, in reach of speech and touch, but also because individuals from the audience inscribe their agencies into the songs through dedications. This kind of performance is more localized than, say, a typical rock, pop or folkloric concert. It literally bears the names of (some of) the listeners. On the other hand, manele songs piece together worlds which seem incompatible, both with one another and with the actual performance context.

As another example, consider Gicuță din Apărători singing:

"I would steal all the gold in Turkey and Arabia for your beauty [...] // I will take you to the sea, to the mountain [...] with a rocket, I will take you all over the globe. // I will take you to the sea, to the mountain [...] by plane, with my BMW, to make you famous in our neighbourhood". ${ }^{22}$

This lightly humorous enumeration of sites and means of locomotion takes place in a Roma wedding in Olteniţa, some $80 \mathrm{~km}$ from Bucharest. On the one hand, no doubt, the performance is precisely there: the recording is sprinkled with dedications of the bride to her mother, her husband, her godmother, and with names of other people in the audience (inserted by the singer of his own initiative, to cheer them up, or as a mark of respect). But on the other hand, none of them is there "as usual": their names resonate widely, in the echoic

22 Gicuţă din Apărători is well known amongst the lăutari in Bucharest. In 2009-2010, he was one of the main manele singers in the capital, "resident" musician at Hanul Drumeţului, a famous restaurant and club. Along the years, he had carefully selected the musicians in his band, and as a whole, the latter was remarkably stable and trained. Apart from Hanul Drumeţului, Gicuţă used to be hired for various events, mainly in Roma communities. He was most often asked to perform manele songs, but his repertoire extended into other genres as well. The complete recording and its translation are available on <www.svictor.net/enchanting-spaces $>$. 
voice of the singer, over synthetic drones and drums. Some kind of relation is suggested between these people - and actually all the dancers - and the exotic images of the rocket, Turkey, Arabia, the mountain, the sea, the BMW... After which the neighbourhood's triviality slaps back with an ironic effect. The melodic line also drives imaginations away from Olteniţa, as the band performs in a kind of Phrygian mode, with powerful riffs on the clarinet and the violin suggesting "oriental" ornaments. The two instruments play in parallel thirds, a feature which is also relatively "exotic" (absent from the official Romanian "folklore" for example), and possibly inspired by Bulgarian and Macedonian music. Through amplification, mixing and echoicity, such features gain spatiality and transform into an "effectively enacted utopia": in short, a "heterotopia". There is a different Olteniţa going on in sound, altogether disconnected, and intimately related to the participants' reality.

\section{CONCLUSIVE REMARKS}

\section{Music as enchantment}

Amplification, mixing, reverberation and echo deal with space, at the junction of musical and natural acoustics. Their importance has been underestimated by ethnomusicologists, possibly because it is underestimated by their informants too. Amplified or electronic music do not constitute a distinct category in local typologies. Lăutari take pride in their (idealized) capacity to perform in any context and several of them explained to me that the absence of amplification should not be a problem for the good musician. On closer inspection however, this is a rather theoretical assumption.

A significant number of recent tunes require substantial arrangements to be performed without electronics. ${ }^{23}$ Furthermore, young musicians have integrated echo, reverberation, and the possibilities offered by the microphone to the core of their performance skills, and are uncomfortable performing even the most traditional songs without amplification. Violinists for example have developed intricate ornaments and melismas which can only be obtained softly. Without microphones, most of what makes these young player's pride remains simply unheard. Confronted with "acoustic" versions of their favorite songs, musicians and customers also voiced the opinion that some musical genres like the manea - loose much of their charm without consistent loudness and wide echo resonance. These are all hints to the fact that musical electronics have entered the core of lăutari's techniques and listeners' expectations.

23 It may happen that musicians are required to perform unamplified for short ritual moments at events such as weddings or christenings. Their repertoire for these circumstances has become very limited. It comprises mainly tunes in the "older" traditional styles. It is rare for example that the fashionable manele be heard on such occasions. 
In this study I have voluntarily let aside most "structural" elements of lăutari's performances. Tunes, rhythms, lyrics, styles, "tricks" (şmecherii) are of course most important for musicians and listeners. They differentiate regional or individual styles, which are the topics of most discussion amongst the local connoisseurs. The omnipresence of amplification, reverberation and echo throughout the country and its musical genres contrasts with these differences. On these grounds - and considering the abundance of works already available on lăutari's music - it seemed legitimate to focus on the effects, independently of the musical structures which they actually process.

This has the side advantage of facilitating cross-cultural comparisons. The effects are well circumscribed, as they relate to a small set of acoustic phenomena. On these grounds, it was possible to characterize the way the lăutari use them, in contrast with other sound cultures. Firstly, the lăutari use echo as a performance technique, and only for live interactions, an approach different from Anglo-Saxon rock (Doyle 2005; Zak 2001), as well as Nepali lok pop (Greene 2002) for example. Secondly, they speak of reverb and echo as ontological properties of sounds, as performance helpers, but not, in my experience, as evocations of places which actually exist. Artificiality and "special effects" are more in line with their general preferences than topological accuracy. In manele locations are often evoked but in deliberately paradoxical combinations. ${ }^{24}$ Thirdly, the lăutari use echo and reverberation to larger extents than Western pop musicians. They apply them with longer decay times and more systematically, to all the instruments and all the tunes which they play. In their hands, these techniques are not features of particular songs, but cornerstones of homogenous musical spaces, in which all their repertoire can be developed, with its contrasted emotional shades.

\section{Tracing further research}

According to Gell $(1988,1992,1996,2006)$ techniques of enchantment are techniques which aim to alter the way we perceive our world. Gell locates in this ensemble "artistic" and "magical" techniques, offering several examples of their close relatedness. This theory of art and magic was developed with durable objects in mind, but its author pointed out that it could hold as well for performances (see Gell 1998: 13, 95, and 2006). It is particularly adequate for those of Roma lăutari, as the latter comment explicitly on their aim to

24 It is interesting to note that topological coherence is of primary importance in another popular musical genre: the "folkloric songs" (cântece folclorice). These are sprinkled with names of villages, valleys, mountain tops, tools, dresses, which should all belong to the same "ethnographic area" (arie etnografică). They are sometimes performed by Roma professional musicians, but the bulk of their performers are supposed to be ethnic Romanians. On the construction of this genre during the communist regime, see Rădulescu (2002). 
manipulate other people's feelings through music. ${ }^{25}$ Going amplified, they take advantage of the available spatialization effects to enforce the disconnection of the sound realm from the "real" world.

According to Scruton (1997), some kind of disconnection grounds all musical perception.

"Hearing sound involves the exercise of the ear: it displays an acoustic capacity, and all that we hear when we hear sounds are the secondary properties of sound events. Animals also hear these properties, and respond to sounds and to the information contained in sounds. But to hear music [...] we must be able to hear an order that contains no information about the physical world, which stands apart from the ordinary workings of cause and effect, and which is irreducible to any physical organization. At the same time, it contains a virtual causality of its own, which animates the elements that are joined by it" (Scruton 1997: 39).

Disconnecting sounds from the material events which cause them is a prerequisite to feeling that some sounds are "caused" by others. This, in turn, is essential for musical expectancies to arise (on musical causality see also Ockelford 1991, 2004). Artificial spatialization techniques can play a role in both the disconnection and re-immersion processes, as lăutari's practices illustrate. Ethnographic accounts from more musical traditions are needed to understand this issue.

What is at stake is the articulation between our perception of musical and non-musical spaces. How do they relate to each other? This question is of course larger than the use of artificial echo and reverb. But the latter offer a vantage point to dive into it, as they play on the ambiguities between the properties of the sounds, and those of the places where they sound.

25 For a discussion of Gell's proposals in relation to Roma professional musicians, see Stoichiţă (2009, $2011)$ and Bonini-Baraldi (2013). 


\section{REFERENCES}

AMY DE LA BRETÈQUE, Estelle, and Victor A. STOICHIŢĀ, 2012, "Musics of the new times Romanian manele and Armenian rabiz as icons of post-communist changes", in Ivan Biliarsky and Ovidiu Cristea (eds.), The Balkans and the Caucasus: Parallel Processes on the Opposite Sides of the Black Sea. Cambridge, Cambridge Scholars Publishing, 321-335. BEISSINGER, Margaret, 1991, The Art of the Lautar: The Epic Tradition of Romania. New York, Taylor \& Francis.

BEISSINGER, Margaret, 2001, “Occupation and ethnicity: constructing identity among professional Romani (Gypsy) musicians in Romania”, Slavic Review, 60 (1): 24-49.

BEISSINGER, Margaret, 2007, "Muzică orientală: identity and popular culture in postcommunist Romania”, in Donna A. Buchanan (ed.), Balkan Popular Culture and the Ottoman Ecumene: Music, Image and Regional Political Discourse. Lanham, MD; Toronto; Plymouth, UK, The Scarecrow Press, 95-141.

BLAUERT, Jens, 1997, Spatial Hearing: The Psychophysics of Human Sound Localization. Cambridge, MA, The MIT Press.

BONINI-BARALDI, Filippo, 2013, Tsiganes, musique et empathie. Paris, Maison des Sciences de l'Homme.

BuCHANan, Donna A. (ed.), 2007, Balkan Popular Culture and the Ottoman Ecumene: Music, Image, and Regional Political Discourse. Lanham, MD; Toronto; Plymouth, UK, The Scarecrow Press.

CIOBANU, Gheorghe, 1969, Lăutarii din Clejani: Repertoriu şi Stil de Interpretare. Bucarest, Editura Muzicală a Uniunii Compozitorilor.

DOUGLAS, Gavin, 2005, "Burmese music and the world market", Anthropology Today, 21 (6): 5-9.

DOYLE, Peter, 2004, “From 'My Blue Heaven' to 'Race with the Devil': echo, reverb and (dis)ordered space in early popular music recording", Popular Music, 23 (1): 31-49.

DOYLE, Peter, 2005, Echo and Reverb: Fabricating Space in Popular Music, 1900-1960. Middletown, CT, Wesleyan University Press.

FOUCAULT, Michel, 1984, "Des espaces autres" (conférence au Cercle d'Etudes Architecturales, 14 mars 1967), Architecture, Mouvement, Continuité, 5: 46-49.

FREDERICKSON, Jon, 1989, “Technology and music performance in the age of mechanical reproduction", International Review of the Aesthetics and Sociology of Music, 20 (2): 193-220.

FRITH, Simon, 1981, Sound Effects: Youth, Leisure, and the Politics of Rock ' $n$ ' Roll. New York, Pantheon Books.

GELL, Alfred, 1988, “Technology and magic”, Anthropology Today, 4 (2): 6-9.

GELL, Alfred, 1992, "The technology of enchantment and the enchantment of technology", in J. Coote and A. Shelton (eds.), Anthropology, Art and Aesthetics. Oxford, Clarendon Press, 40-63.

GELL, Alfred, 1996, "Vogel's net: traps as artworks and artworks as traps", Journal of Material Culture, 1 (1): 15-38.

GELL, Alfred, 1998, Art and Agency: An Anthropological Theory. Oxford, Clarendon Press.

GELL, Alfred, 2006, "Parfum, symbolisme et enchantement", Terrain, 47: 19-34.

GIURCHESCU, Anca, and Speranța RÁDUlESCU, 2011, "Music, dance, and expressive behaviour in a new form of expressive culture: the Romanian manea", Yearbook for Traditional Music, 43: 1-36. 
GREENE, Paul D., 2002, “Nepal's 'lok pop' music: representations of the folk, tropes of memory, and studio technologies”, Asian Music, 34 (1): 43-65.

GRIMAUD, Emmanuel, Sophie HOUDART, and Denis VIDAL, 2006, "Artifices et effets spéciaux: Les troubles de la représentation", Terrain, 46: 5-14.

HESSELINK, Nathan, 1994, "Kouta and karaoke in modern Japan: A blurring of the distinction between Umgangsmusik and Darbietungsmusik", British Journal of Ethnomusicology, 3: 49-61.

LEVIN, Theodore, 1993, “The reterritorialization of culture in the new Central Asian states: A report from Uzbekistan”, Yearbook for Traditional Music, 25: 51-59.

LORTAT-JACOB, Bernard, 1994, Musiques en fête. Nanterre, Société d'Ethnologie.

MOORE, Allan F, 2001, Rock, the Primary Text: Developing a Musicology of Rock. Aldershot, Ashgate.

OCKELFORD, Adam, 1991, "The role of repetition in perceived musical structures", in Peter Howell, Robert West and Ian Cross (eds.), Representing Musical Structure. London, Academic Press, 129-159.

OCKELFORD, Adam, 2004, "On similarity, derivation and the cognition of musical structure", Psychology of Music, 32 (1): 12-74.

OIŞTEANU, Andrei, 2001, "Ţara meşterului manele", 22, 29, available at <http://www. pruteanu.ro/9ultima/oisteanu-manele-22.htm> (consulted 25/09/2013).

OLIVERA, Martin, 2012, La tradition de l'intégration: une ethnologie des Roms Gabori dans les années 2000. Paris, Pétra.

PETTAN, Svanibor, 1996, "Selling music, Rom musicians and the music market in Kosovo", in Ursula Hemetek (ed.), Echo der Vielfalt: Traditionelle Musik von Minderheitethnischen Gruppen / Echoes of Diversity: Traditional Music of Ethnic Groups-Minorities. Vienna, Böhlau, 233-243.

RĂDULESCU, Speranţa, 1984, “Istoria tarafului tradiţional sătesc trăită şi comentată de lăutarii înşişi. Secolul XX”, Revista de Etnografie şi Folclor, 29 (2): 159-170.

RĀDULESCU, Speranţa, 1988, "La formation du Lautar roumain”, Cahier des Musiques Traditionnelles, 1: 87-99.

RĀDULESCU, Speranţa, 1996, "Fiddlers' contracts and payments", East European Meetings in Ethnomusicology, 3: 76-83.

RÃDULESCU, Speranţa, 1997, "Analiza unui text muzical lăutăresc”, Revista de Etnografie şi Folclor, 22 (1): 31-61.

RÃDUleSCU, Speranţa, 2002, Peisaje muzicale în România secolului XX. Bucarest, Editura Muzicală.

RĂDULESCU, Speranţa, 2004, Taifasuri despre muzica ţigănească. Bucarest, Paideia.

SAID, Edward W., 1979, Orientalism. New York, Vintage Books.

SCRUTON, Roger, 1997, The Aesthetics of Music. Oxford, Clarendon Press.

SILVERMAN, Carol, 2012, Romani Routes: Cultural Politics and Balkan Music in Diaspora. Oxford, Oxford University Press.

STOICHIŢA, Victor A., 2008, Fabricants d'émotion: musique et malice dans un village tsigane de Roumanie. Nanterre, Société d'Ethnologie.

STOICHIŢÃ, Victor A., 2009, "Pensée motivique et pièges à pensée: musique, tissage et œufs de Pâques en Moldavie”, L'Homme, 192: 23-38.

STOICHIŢĂ, Victor A., 2010, “Les 'voleurs intelligents' ou l'éthique de la créativité selon les musiciens professionnels tsiganes de Roumanie”, Gradhiva, November 24, 12: 80-97. 
STOICHIŢÃ, Victor A., 2011, "Quand la mélodie ruse: L'enchantement musical et ses acteurs", in Sophie Houdart and Olivier Thiery (eds.), Humains, non humains: Comment repeupler les sciences sociales. Paris, La Découverte, 311 -320.

STOICHIŢÃ, Victor A., 2013, "Vous trouvez cela drôle? Ironie et jeux relationnels dans une nouvelle musique de fête en Roumanie”, Cahiers d'Ethnomusicologie, 26: 193-208.

STROFFrEGEN, Thomas A., and John B. PITTENGER, 1995, "Human echolocation as a basic form of perception and action”, Ecological Psychology, 7 (3): 181-216.

VOICULESCU, Cerasela, 2005, "Production and consumption of folk-pop music in post-socialist Romania: discourse and practice”, Ethnologia Balkanica, 9: 261-283.

ZAK, Albin, 2001, The Poetics of Rock: Cutting Tracks, Making Records. Berkeley, University of California Press. 